\title{
Differential Regulation of Neurotrophin and trk Receptor mRNAs in Catecholaminergic Nuclei during Chronic Opiate Treatment and Withdrawal
}

\author{
Suzanne Numan, ${ }^{1}$ Sarah B. Lane-Ladd, ${ }^{1,2}$ Lixin Zhang, ${ }^{4}$ Kerstin H. Lundgren, ${ }^{4}$ David S. Russell, ${ }^{1,3}$ \\ Kim B. Seroogy, ${ }^{4}$ and Eric J. Nestler ${ }^{1,2}$ \\ ${ }^{1}$ Laboratory of Molecular Psychiatry, Departments of ${ }^{1}$ Psychiatry, ${ }^{2}$ Neurobiology, and ${ }^{3}$ Neurology, Yale University School \\ of Medicine and Connecticut Mental Health Center, New Haven, Connecticut 06508, and ${ }^{4}$ Department of Anatomy and \\ Neurobiology, University of Kentucky College of Medicine, Lexington, Kentucky 40536
}

The neurotrophins brain-derived neurotrophic factor (BDNF) and neurotrophin-3 (NT-3) and their receptors trkB and trkC, respectively, are expressed in the locus coeruleus (LC) and ventral tegmental area (VTA), brain regions known to be involved in opiate addiction. Previously, administration of exogenous neurotrophins has been shown to oppose effects of chronic morphine treatment on LC and VTA neurons. However, the response of endogenous neurotrophins in LC and VTA to opiate treatment is unknown. In this study, BDNF, NT-3, trkB, and trkC mRNAs were analyzed in these regions after chronic morphine treatment and during antagonist precipitated withdrawal. Although chronic morphine exposure resulted in only modest increases in BDNF and NT-3 mRNA expression in LC, precipitated withdrawal led to a marked, rapid, and prolonged increase in BDNF mRNA and a delayed decrease in NT-3
mRNA. Levels of trkB and trkC mRNAs, which were unchanged by chronic morphine treatment, were elevated in LC at 2 and 6 hr of withdrawal. By 20 hr, trkB mRNA levels in LC had returned to control, whereas trkC mRNA levels fell below control values. In contrast to the substantial alterations observed in LC, there was no regulation of the neurotrophins or trk mRNAs within the VTA during chronic opiate treatment or withdrawal, with the exception of an increase in trkB mRNA at $6 \mathrm{hr}$ of withdrawal. These results suggest that neurotrophins and their receptors per se may be involved in opiate-induced plasticity of the LC, whereas other mechanisms would appear to be involved in the VTA.

Key words: locus coeruleus; ventral tegmental area; opiates; neurotrophins; neural plasticity; morphine
The locus coeruleus (LC), the major noradrenergic cell group in the brain (for review, see Aston-Jones et al., 1995), has been implicated in opiate physical dependence and withdrawal (Nestler and Aghajanian, 1997). Acutely, opiates inhibit LC neuronal activity (Korf et al., 1974; Bird and Kuhar, 1977; Valentino and Wehby, 1988). In response to continued opiate treatment, several long-term biochemical alterations occur in LC, including increases in tyrosine hydroxylase, adenylyl cyclase, and protein kinase A (Duman et al., 1988; Nestler and Tallman, 1988; Guitart et al., 1990; Nestler et al., 1993). In addition, tolerance develops such that LC neuronal firing rates return toward control levels, and the neurons show dependence such that abrupt opiate removal causes marked increases in LC neuronal activity (Aghajanian, 1978; Valentino and Wehby, 1989; Rasmussen et al., 1990). This increase in LC activity appears both necessary and sufficient to induce many opiate withdrawal behaviors (Grant et al., 1988; Maldonado and Koob, 1993; Nestler and Aghajanian, 1997).

Another catecholaminergic nucleus implicated in opiate addiction is the ventral tegmental area (VTA) (Wise, 1996; Koob and Le Moal, 1997; Koob and Nestler, 1997). This nucleus, which

\footnotetext{
Received July 20, 1998; revised Sept. 29, 1998; accepted Oct. 1, 1998.

This study was supported by grants from the National Institute on Drug Abuse, by the Abraham Ribicoff Research Facilities of the Connecticut Mental Health Center, State of Connecticut, Department of Mental Health and Addiction Services (E.J.N., D.S.R.), and by National Institutes of Health Grant NS35164 and National Alliance for Research on Schizophrenia and Depression (NARSAD) (K.B.S.).

Correspondence should be addressed to Dr. Eric J. Nestler, Laboratory of Molecular Psychiatry, 34 Park Street, New Haven, CT 06508.

Copyright (C) 1998 Society for Neuroscience 0270-6474/98/1810700-09\$05.00/0
}

contains dopaminergic neurons that project to the nucleus accumbens and other forebrain regions (for review, see Lindvall and Björklund, 1983), is thought to be involved in rewarding aspects of opiate administration. Like the LC, the VTA undergoes long-term biochemical changes after chronic opiate exposure, including increases in tyrosine hydroxylase and certain glutamate receptor subunits and decreases in neurofilaments (Nestler et al., 1993, 1996). Although opiates acutely activate VTA dopamine neurons by inhibiting inhibitory interneurons (Johnson and North, 1992), the chronic electrophysiological effects of opiates on these cells have only recently been investigated (Bonci and Williams, 1997).

Recent evidence suggests that neurotrophins, in addition to their well known roles in neuronal development and survival, may be involved in maintenance of neuronal phenotype, neuronal plasticity, and neuroprotection for adult neurons (Gall, 1993; Korsching, 1993; Lindsay et al., 1994). Brain-derived neurotrophic factor (BDNF) and neurotrophin-3 (NT-3) are two neurotrophins that increase survival of LC neurons (Friedman et al., 1993; Sklair-Tavron and Nestler, 1995) and ventral midbrain dopamine neurons (Hyman et al., 1991, 1994; Spenger et al., $1995)$ in vitro. Both BDNF and NT-3 mRNAs and their cognate receptor mRNAs trkB and trkC, respectively, are expressed in adult LC (Seroogy, 1994; Smith et al., 1995; Zhang et al., 1998) and VTA (Gall et al., 1992; Seroogy and Gall, 1993; Altar et al., 1994; Seroogy et al., 1994; Numan and Seroogy, 1998). Furthermore, neurotrophin mRNA expression can be regulated in these 
nuclei by specific pharmacological treatments (Numan and Seroogy, 1994; Seroogy, 1994; Hung and Lee, 1996).

Recent studies suggest a role for neurotrophins in opiate addiction. Administration of exogenous BDNF or NT-3 opposes effects of chronic opiate treatment on LC neurons in vitro (SklairTavron and Nestler, 1995) and on VTA neurons in vivo (Berhow et al., 1995; Sklair-Tavron et al., 1996). However, the response of endogenous neurotrophin systems in the LC and VTA to opiate treatment is unknown. In the present study, expression of $\mathrm{mR}$ NAs for BDNF and NT-3 and for their high-affinity receptors trkB and trkC, respectively, was examined in the LC and VTA after chronic morphine treatment and during opiate withdrawal to study possible plasticity of these neurotrophin systems in the context of opiate addiction.

\section{MATERIALS AND METHODS}

\section{Animals and treatments}

Adult male Sprague Dawley rats (150-200 gm; $n=32$; CAMM, Wayne, $\mathrm{NJ})$ were used for this study. The opiate treatment paradigms used in these experiments followed protocols described previously by Rasmussen and colleagues (1990).

Chronic morphine. For $5 \mathrm{~d}$, once a day, rats $(n=4)$ were lightly anesthetized with fluothane and implanted with a morphine pellet ( 75 mg of morphine base; National Institute on Drug Abuse) subcutaneously. Control rats $(n=4)$ were lightly anesthetized but not implanted with pellets. On day six all rats were decapitated.

Morphine withdrawal (short-term survival). Rats were treated as above; however, on day six, sham-treated rats $(n=4)$ were injected with $0.9 \%$ saline subcutaneously and decapitated $2 \mathrm{hr}$ later. Morphine-treated rats were injected with naltrexone $(100 \mathrm{mg} / \mathrm{kg}$ in $0.9 \%$ saline, s.c.), housed individually, and decapitated $2 \mathrm{hr}(n=4)$ or $6 \mathrm{hr}(n=4)$ after the injection.

Morphine withdrawal (long-term survival). Rats were treated as in the chronic morphine paradigm; however, on day six, sham-treated rats $(n=$ 4) were killed by rapid decapitation. Morphine-treated rats had their last two implanted morphine pellets removed under light fluothane anesthesia and then were injected with naltrexone $(100 \mathrm{mg} / \mathrm{kg}$ in $0.9 \%$ saline, s.c.) and housed separately. After $6 \mathrm{hr}$ of withdrawal, rats received another injection of naltrexone. Some of the rats $(n=4)$ were decapitated after $20 \mathrm{hr}$ of withdrawal. Finally, the remaining group $(n=4)$ received a third injection of naltrexone after $24 \mathrm{hr}$ of withdrawal and were decapitated at $70 \mathrm{hr}$. For the long withdrawal periods, rats were supplied with mashed food and water in the cage with them as well as with a local heat source.

\section{Tissue collection}

After decapitation, brains were quickly removed and frozen with dry ice. Coronal sections $(10 \mu \mathrm{m})$ throughout the rostrocaudal extent of the LC and the VTA were cut in a cryostat, thaw-mounted onto Superfrost Plus (Fisher Scientific, Pittsburgh, PA) glass slides, and stored at $-20^{\circ} \mathrm{C}$ until hybridization.

\section{In situ hybridization}

Coronal sections through the rostrocaudal extent of the LC and VTA were processed for the in situ hybridization localization of BDNF, NT-3, trkB, and trkC mRNAs by using ${ }^{35} \mathrm{~S}$-labeled cRNA probes as described previously (Seroogy et al., 1994; Numan and Seroogy, 1997; Seroogy and Herman, 1997). These nuclei were identified by standard anatomical landmarks (Paxinos and Watson, 1986). Briefly, the slide-mounted sections were brought to room temperature and then placed in $4 \%$ paraformaldehyde for $10 \mathrm{~min}$. This was followed by washes in $0.1 \mathrm{~m}$ phosphate buffer (PB), $0.1 \mathrm{M} \mathrm{PB} / 0.2 \%$ glycine, and $0.25 \%$ acetic anhydride in $0.1 \mathrm{M}$ triethanolamine. The sections were then dehydrated with increasing concentrations of ethanol, delipidated in chloroform, and air-dried. Sections were hybridized overnight at $60^{\circ} \mathrm{C}$ in a hybridization mixture consisting of $10 \%$ dextran sulfate, $50 \%$ formamide, $1 \times$ Denhardt's solution, $0.15 \mathrm{mg} / \mathrm{ml}$ yeast tRNA, $40 \mathrm{~mm}$ dithiothreitol, $0.33 \mathrm{mg} / \mathrm{ml}$ denatured salmon sperm DNA, 1 mM EDTA, $20 \mathrm{~mm}$ Tris- $\mathrm{HCl}$, and the ${ }^{35}$ S-labeled cRNA probe at a concentration of $1.0 \times 10^{6} \mathrm{cpm} / 50 \mu \mathrm{l}$ per slide. Sense and antisense cRNA probes were prepared by in vitro transcription using linearized DNA constructs in the presence of RNA polymerase (T3, T7, or SP6) and ${ }^{35}$ S-UTP (New England Nuclear, Boston, MA). BDNF and NT-3 cDNA constructs (kindly supplied by J. Lauterborn and C. Gall, University of California at Irvine) resulted in antisense transcripts that were 540 and 550 bases long, respectively. The cDNA constructs for trkB and trkC (generous gifts from D. McKinnon, State University of New York at Stony Brook) resulted in antisense RNA transcripts that were 196 and 300 bases long, respectively. The trkB cRNA probe used in this study detected only the kinase-specific, fulllength catalytic form of the receptor mRNA (Sternini et al., 1996). In contrast, the probe used to detect trkC mRNA recognized mRNA transcripts for both the full-length catalytic and truncated noncatalytic forms of the receptor (Dixon and McKinnon, 1994; Albers et al., 1996).

For treatment after hybridization, sections were washed several times in $4 \times \operatorname{SSC}(1 \times \mathrm{SSC}=0.15 \mathrm{~m}$ sodium chloride, $0.015 \mathrm{~m}$ sodium citrate, $\mathrm{pH}$ 7.0) containing $10 \mathrm{~mm}$ sodium thiosulfate, at $37^{\circ} \mathrm{C}$. The sections were then incubated in ribonuclease $\mathrm{A}(0.05 \mathrm{mg} / \mathrm{ml})$ for $30 \mathrm{~min}$ at $45^{\circ} \mathrm{C}$. This was followed by several washes in decreasing concentrations of SSC (2, 0.5 , and $0.1 \times$ ) at $37^{\circ} \mathrm{C}$. All but the final wash also contained $10 \mathrm{~mm}$ sodium thiosulfate. The sections were briefly rinsed in $\mathrm{dH}_{2} 0$, dipped in $95 \%$ ethanol, and finally air-dried. To generate film autoradiograms the sections were exposed to $\beta$-Max Hyperfilm (Amersham, Arlington Heights, IL) for 7-15, 7-18, 14-22, and 21-25 d for trkC, trkB, BDNF, and NT-3 mRNAs, respectively. It should be noted that the variability in film exposure for a single probe comes from the different experiments (chronic morphine, 2 and $6 \mathrm{hr}$ morphine withdrawal, or 20 and $70 \mathrm{hr}$ withdrawal in LC or VTA) and not from within a single experiment. Therefore, for each probe all of the groups for one experiment (e.g., control, 2 and $6 \mathrm{hr}$ withdrawal in LC) were processed at the same time and were on film for the same amount of time. As controls for specificity, some sections were pretreated with ribonuclease A $(0.05 \mathrm{mg} / \mathrm{ml})$ for 30 min at $45^{\circ} \mathrm{C}$ before hybridization with the ${ }^{35} \mathrm{~S}$-labeled cRNA probes. Some sections were also hybridized with BDNF, NT-3, trkB, or trkC sense strand ${ }^{35} \mathrm{~S}$-labeled riboprobes. No specific labeling was observed under any of these control conditions.

Film autoradiograms were analyzed by densitometry using NIH Image software to compare densities of hybridization of each probe in the LC and VTA between control rats and treated rats. From each animal, at least six measurements of hybridization density, also referred to as gray level, were taken for each probe from both LC and VTA. A paired background measurement was subtracted from each gray level, leading to a corrected gray level. Once a mean corrected gray level for LC and VTA was attained for each animal, statistical analysis was performed. Statistical analysis included Student's unpaired $t$ test and ANOVA followed by Student Newman-Keuls post hoc analyses where appropriate. The NIH image software was also used to acquire images of representative sections from film autoradiograms.

\section{RESULTS}

\section{Locus coeruleus}

\section{Chronic morphine}

Coronal sections throughout the LC of control and morphinetreated rats were processed for the in situ hybridization localization of BDNF, NT-3, trkB, and trkC mRNAs. Densitometric analysis of film autoradiograms revealed a small but significant increase $(+10 \pm 1.8 \%)$ in BDNF mRNA expression in the LC after chronic morphine treatment as compared with control rats $(p<0.05)$ (Fig. 1A, Table 1). Similarly, chronic morphine administration induced a slight increase $(+8 \pm 1.9 \%)$ in NT-3 mRNA expression in this brain region $(p<0.05)$ (Fig. $1 B$, Table 1). In contrast to the small increases in neurotrophin mRNA expression in the $\mathrm{LC}$ after chronic opiate treatment, $t r k \mathrm{~B}$ and $t r k \mathrm{C}$ cRNA hybridization densities were not significantly altered $(p>$ 0.05) (Fig. 1C,D, Table 1). However, it should be noted that there did appear to be a trend toward a decrease $(-9 \pm 2.1 \%)$ in $t r k \mathrm{C}$ mRNA levels in morphine-treated versus control rats $(p=0.062)$ (Fig. 1D, Table 1). 
A

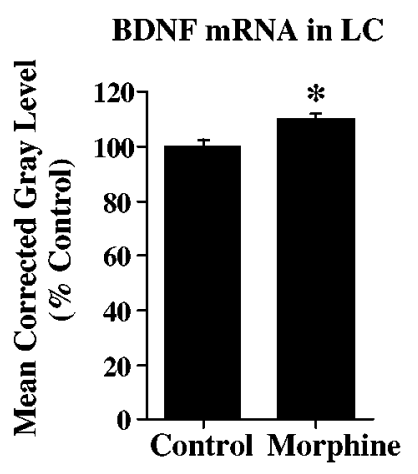

$\mathbf{C}$

trkB mRNA in LC

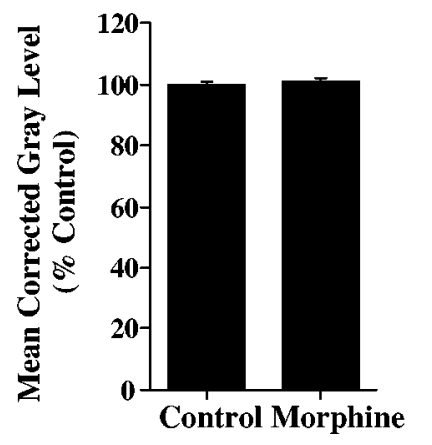

B

\section{NT-3 mRNA in LC}

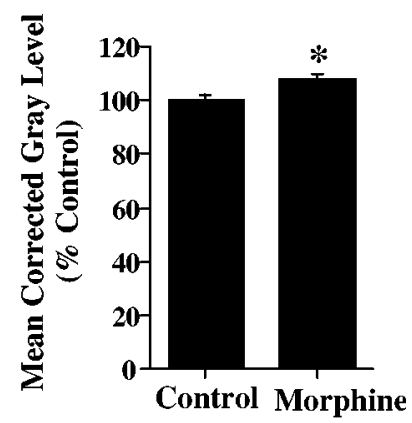

D

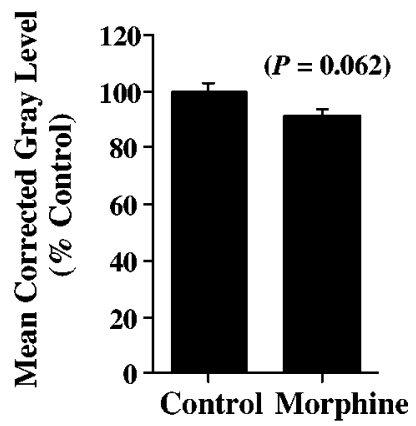

Figure 1. Analysis of $\operatorname{BDNF}(A), \mathrm{NT}-3(B), \operatorname{trkB}(C)$, and trkC $(D)$ mRNA expression in LC after chronic opiate treatment. Note the significant increase in $\operatorname{BDNF}(A)$ and NT-3 $(B)$ mRNA levels (asterisks) in LC after chronic opiate exposure. Although there was a trend toward a decrease in trkC mRNA levels $(D ; p=0.062)$, no significant alterations in $\operatorname{trk\mathrm {B}}(C)$ or $\operatorname{trk\mathrm {C}}(D)$ mRNA expression were observed in LC with chronic morphine treatment. Results are expressed as a percentage of control values. Values are the mean \pm SEM.

\section{Morphine withdrawal}

Visual inspection of film autoradiograms revealed a substantial increase in BDNF mRNA levels in the LC after $2 \mathrm{hr}$ of morphine withdrawal as compared with control animals (Fig. 2A). There also appeared to be a further elevation in the BDNF cRNA hybridization density after $6 \mathrm{hr}$ of withdrawal (Fig. $2 A$ ). Densitometric analysis of film autoradiograms confirmed that there were significant alterations in BDNF mRNA levels during precipitated opiate withdrawal $\left[F_{(2,8)}=223.451 ; p<0.001\right]$. Post hoc analyses revealed that BDNF mRNA levels were significantly raised at $2 \mathrm{hr}(+100 \pm 5 \%)$ and $6 \mathrm{hr}(+147 \pm 1 \%)$ of morphine withdrawal as compared with control levels $(p<0.05)$ (Fig. $2 C$, Table 1). Furthermore, BDNF mRNA levels in the LC were higher at $6 \mathrm{hr}$ of morphine withdrawal than at $2 \mathrm{hr}(p<0.05)$ (Fig. 2C, Table 1).

To study the duration of BDNF mRNA induction during withdrawal, another set of animals was processed for the in situ hybridization localization of the neurotrophins and their receptors in the LC after longer withdrawal periods. As with the earlier time points, robust increases in BDNF mRNA levels occurred after longer periods of withdrawal $\left[F_{(2,9)}=69.717 ; p<0.001\right]$. BDNF mRNA levels were significantly increased at both $20 \mathrm{hr}$ $(+294 \pm 7 \%)$ and $70 \mathrm{hr}(+192 \pm 29 \%)$ of opiate withdrawal as

compared with controls ( $p<0.05$ ) (Fig. $2 B, C$, Table 1$)$. It should be noted that there was a significant reduction in BDNF mRNA levels at $70 \mathrm{hr}$ of withdrawal as compared with $20 \mathrm{hr}(p<0.05)$ (Fig. 2B,C, Table 1), indicating a partial return toward control levels.

In contrast to the increase in BDNF mRNA expression in the LC during morphine withdrawal, densitometric analysis of film autoradiograms revealed no significant alterations in NT-3 mRNA levels at 2 or $6 \mathrm{hr}$ of withdrawal as compared with controls $\left[F_{(2,8)}=1.029 ; p>0.1\right]$ (Fig. 3A,C, Table 1). However, significant reductions in NT-3 mRNA levels were found after the longer opiate withdrawal periods $\left[F_{(2,9)}=70.719 ; p<0.001\right]$ (Fig. 3B, $C$, Table 1). Post hoc analyses indicated that there was a significant decrease in NT-3 cRNA hybridization in the LC after $20 \mathrm{hr}$ $(-49 \pm 2.9 \%)$ and $70 \mathrm{hr}(-19 \pm 1.3 \%)$ of morphine withdrawal $(p<0.05)$ (Fig. 3C, Table 1$)$. The magnitude of this reduction was significantly smaller at $70 \mathrm{hr}$ as compared with $20 \mathrm{hr}(p<$ 0.05) (Fig. 3C, Table 1).

In film autoradiograms, $t r k \mathrm{~B}$ mRNA expression appeared to be increased in the LC at both 2 and $6 \mathrm{hr}$ of morphine withdrawal as compared with controls (Fig. 4A). Densitometric analysis demonstrated a significant increase in the hybridization density for trkB mRNA after withdrawal $\left[F_{(2,8)}=6.71 ; p<0.02\right]$. Post hoc analyses revealed small but significant increases in trkB mRNA levels at $2 \mathrm{hr}(+11 \pm 2.9 \%)$ and $6 \mathrm{hr}(+9 \pm 2.3 \%)$ of opiate withdrawal $(p<0.05)$ (Fig. $4 C$, Table 1$)$. In contrast, no changes in $t r k \mathrm{~B}$ mRNA levels were observed at 20 and $70 \mathrm{hr}$ of withdrawal as compared with controls ( $p>0.05)$ (Fig. 4B,C, Table 1).

As with trkB, there appeared to be increased trkC mRNA levels in the LC at 2 and 6 hr of morphine withdrawal as compared with controls (Fig. 5A). Densitometric analysis of film autoradiograms confirmed that there were significant changes in the hybridization density for trkC mRNA during withdrawal from morphine $\left[F_{(2,8)}\right.$ $=17.09 ; p<0.01]$. Post hoc analyses showed that trkC mRNA levels were significantly elevated at $2 \mathrm{hr}(+24 \pm 3.8 \%)$ and $6 \mathrm{hr}$ $(+23 \pm 3.7 \%)$ of morphine withdrawal as compared with controls $(p<0.05)$ (Fig. 5C, Table 1). In striking contrast to the effects of early withdrawal, significant reductions in trkC mRNA levels were observed in the LC after longer withdrawal periods $\left[F_{(2,9)}=\right.$ 11.25; $p<0.05$ ] (Fig. 5B, $C$, Table 1). Levels of trkC mRNA were significantly decreased at $20 \mathrm{hr}(-22 \pm 1 \%)$ and $70 \mathrm{hr}(-12 \pm$ $4.2 \%) \mathrm{hr}$ of withdrawal as compared with controls $(p<0.05)$ (Fig. 5C, Table 1).

\section{Ventral tegmental area \\ Chronic morphine}

Coronal sections throughout the VTA of control and morphinetreated rats were processed for the in situ hybridization localization of BDNF, NT-3, trkB, and trkC mRNAs. No changes in neurotrophin or neurotrophin receptor mRNA levels could be detected in the VTAs of opiate-treated rats as compared with controls by visual inspection of film autoradiograms (Fig. 6). Densitometric analysis of film autoradiograms confirmed that there were no alterations in the expression of BDNF, NT-3, trkB, or trkC mRNAs in the VTA after chronic morphine treatment $(p>0.05)$ (Fig. 7). Similarly, there did not appear to be any regulation of the neurotrophins or their receptor mRNAs in the nearby substantia nigra (Fig. 6).

\section{Morphine withdrawal}

At 2 and $6 \mathrm{hr}$ of morphine withdrawal, there were no significant differences in the VTA for BDNF, NT-3, or trkC mRNAs as 


\begin{tabular}{|c|c|c|c|c|}
\hline & BDNF mRNA (\%) & NT-3 mRNA (\%) & $\operatorname{trkB}$ mRNA $(\%)$ & $\operatorname{trkC}$ mRNA $(\%)$ \\
\hline \multicolumn{5}{|c|}{ Chronic morphine } \\
\hline $\mathrm{C}$ & $100 \pm 2.4$ & $100 \pm 2.3$ & $100 \pm 1$ & $100 \pm 3.1$ \\
\hline M & $110 \pm 1.8^{a}$ & $108 \pm 1.9^{a}$ & $101 \pm 1$ & $91 \pm 2.1$ \\
\hline \multicolumn{5}{|c|}{ Morphine withdrawal } \\
\hline $\mathrm{C}$ & $100 \pm 6$ & $100 \pm 4.4$ & $100 \pm 1.1$ & $100 \pm 2.7$ \\
\hline $2 \mathrm{hr}$ & $200 \pm 5^{a}$ & $107 \pm 3.9$ & $111 \pm 2.9^{a}$ & $124 \pm 3.8^{a}$ \\
\hline $6 \mathrm{hr}$ & $247 \pm 1^{b}$ & $100 \pm 3.4$ & $109 \pm 2.3^{a}$ & $123 \pm 3.7^{a}$ \\
\hline \multicolumn{5}{|c|}{ Morphine withdrawal } \\
\hline $\mathrm{C}$ & $100 \pm 6.5$ & $100 \pm 4$ & $100 \pm 1.7$ & $100 \pm 3.7$ \\
\hline $20 \mathrm{hr}$ & $394 \pm 7^{c}$ & $51 \pm 2.9^{d}$ & $96 \pm 2.1$ & $78 \pm 1^{e}$ \\
\hline $70 \mathrm{hr}$ & $292 \pm 29^{a}$ & $81 \pm 1.3^{e}$ & $95 \pm 2.3$ & $88 \pm 4.2^{e}$ \\
\hline
\end{tabular}

Summary of the effects of opiate treatment and withdrawal on neurotrophin and trk receptor mRNA levels in LC. Data are presented as percentage of control. Values are the mean \pm SEM. C, Control; M, morphine. $n=4$ for all groups, except $n=$

3 for the $6 \mathrm{hr}$ withdrawal group. The data given in this table are shown in graphic form in Figures 1-5.

${ }^{a}$ Significantly increased from control.

${ }^{b}$ Significantly increased from control and $2 \mathrm{hr}$.

${ }^{c}$ Significantly increased from control and $70 \mathrm{hr}$.

${ }^{d}$ Significantly decreased from control and $70 \mathrm{hr}$.

${ }^{e}$ Significantly decreased from control.

A

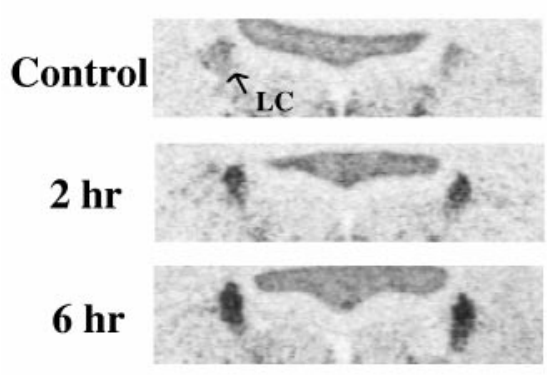

B

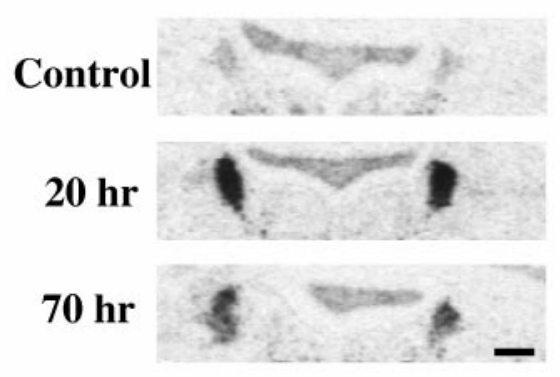

C

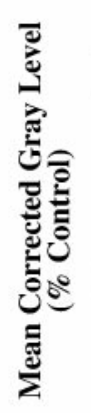

BDNF mRNA in LC

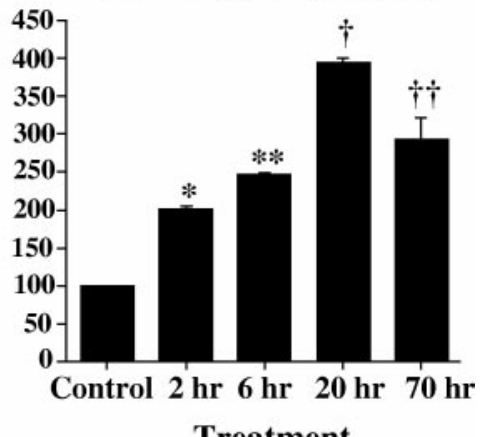

Treatment

Figure 2. Effect of precipitated opiate withdrawal on BDNF mRNA expression in LC. $A$, Film autoradiograms demonstrating BDNF cRNA hybridization in LC of control rats and rats exposed to 2 or $6 \mathrm{hr}$ of opiate withdrawal. $B$, Film autoradiograms of BDNF mRNA expression in LC in control rats and rats exposed to 20 or $70 \mathrm{hr}$ of opiate withdrawal. $C$, Densitometric analysis of film autoradiograms reveals robust increases in BDNF mRNA levels at 2, 6, 20, and $70 \mathrm{hr}$ of opiate withdrawal as compared with control $(p<0.05)$. Results are expressed as a percentage of control values. Values are the mean \pm SEM (SEM for 2 and $6 \mathrm{hr}$ control group $= \pm 6$; SEM for 20 and $70 \mathrm{hr}$ control group $= \pm 6.5$.) ${ }^{*}{ }^{\dagger}$ Significantly increased from control. ** Significantly increased from control and $2 \mathrm{hr}$. ${ }^{\dagger}$ Significantly different from control and $20 \mathrm{hr}$. Scale bar, $500 \mu \mathrm{m}$.

compared with controls $(p>0.05)$ (Fig. $8 A, B, D)$. However, a small but significant effect of morphine withdrawal on trkB mRNA expression was detected in this brain region $\left[F_{(2,9)}=\right.$ 5.094; $p<0.05]$. Post hoc analyses showed a significant increase in trkB mRNA hybridization in the VTA at $6 \mathrm{hr}(+23 \pm 3.9 \%)$ of morphine withdrawal as compared with controls $(p<0.05)$ (Fig. $8 C$ ). Withdrawal had no apparent effect on neurotrophin or trk receptor mRNA levels in the substantia nigra (data not shown).

\section{DISCUSSION}

The results of the present study demonstrate that chronic opiate treatment and withdrawal differentially regulate neurotrophin and their receptor mRNAs in the LC. Chronic morphine treatment led to small, but significant, increases in BDNF and NT-3 mRNA levels and no changes in trkB or trkC mRNAs in this brain region. Precipitated opiate withdrawal resulted in a robust in- crease in BDNF mRNA expression at all time points examined. In contrast to BDNF, there was a decrease in NT-3 mRNA levels at the more prolonged time points $(20$ and $70 \mathrm{hr})$ of withdrawal. Although both trkB and trkC mRNAs were increased at 2 and 6 hr of withdrawal, trkB mRNA had returned to control levels by 20 hr, whereas trkC mRNA levels were reduced to below control values at the 20 and $70 \mathrm{hr}$ withdrawal time points.

It is interesting to note that the modulation of NT-3 mRNA expression in the LC during withdrawal was not immediate. Although BDNF, trkB, and trkC mRNA levels were increased at $2 \mathrm{hr}$ of morphine withdrawal, decreased NT-3 mRNA expression was not observed until $20 \mathrm{hr}$ of withdrawal. There are precedents for a delayed decrease in NT-3 mRNA levels in the brain. For example, experimental brain trauma resulted in a significant increase in BDNF mRNA in the hippocampal dentate gyrus by $1 \mathrm{hr}$ after injury, whereas NT-3 mRNA levels were not signifi- 
A

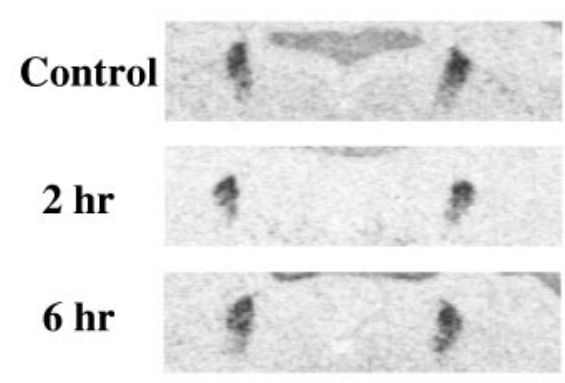

B

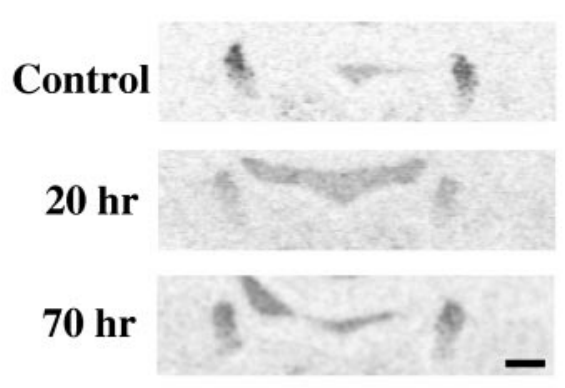

C

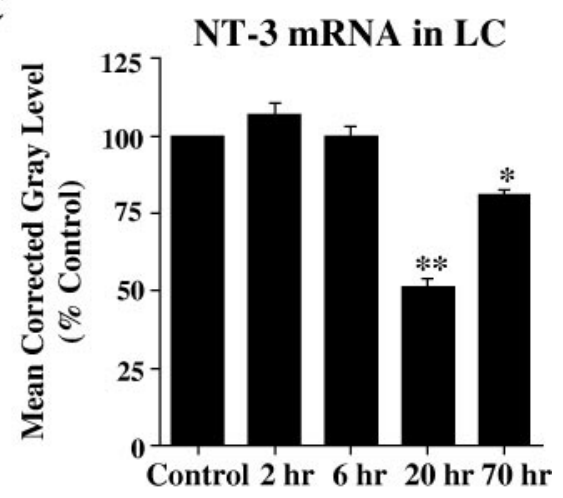

Treatment

Figure 3. Effect of precipitated opiate withdrawal on NT-3 mRNA expression in LC. $A$, Film autoradiograms of NT-3 mRNA expression in LC of control rats and of rats after 2 or $6 \mathrm{hr}$ of opiate withdrawal. $B$, Film autoradiograms demonstrating the expression of NT-3 mRNA in LC of control rats and rats exposed to 20 or $70 \mathrm{hr}$ of opiate withdrawal. $C$, Results from analysis of film autoradiograms show that there are no alterations in NT-3 mRNA levels at 2 and $6 \mathrm{hr}$ of opiate withdrawal as compared with control. In contrast, there was a decrease in NT-3 mRNA levels at 20 and 70 hr of opiate withdrawal as compared with control $(p<0.05)$. Results are expressed as a percentage of control values. Values are the mean \pm SEM (SEM for 2 and $6 \mathrm{hr}$ control group $= \pm 4.4$; SEM for 20 and $70 \mathrm{hr}$ control group $= \pm 4$.) *Significantly decreased from control. **Significantly different from control and $70 \mathrm{hr}$. Scale bar, $500 \mu \mathrm{m}$.

A

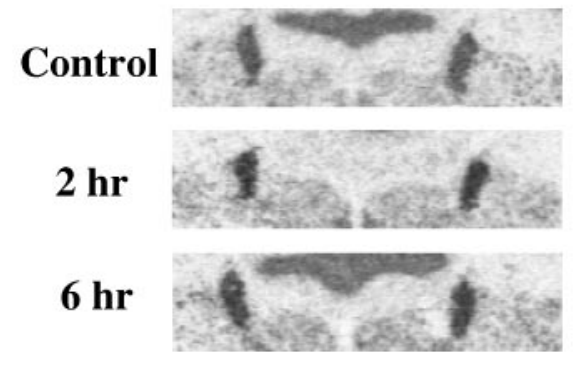

B

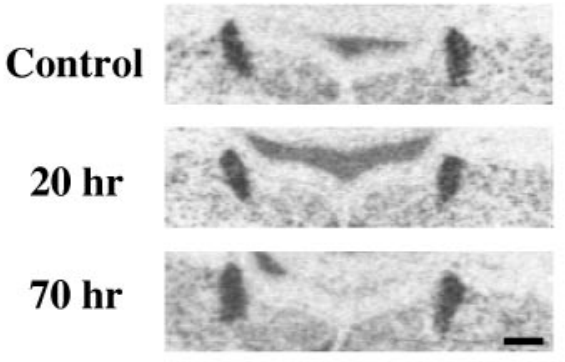

C

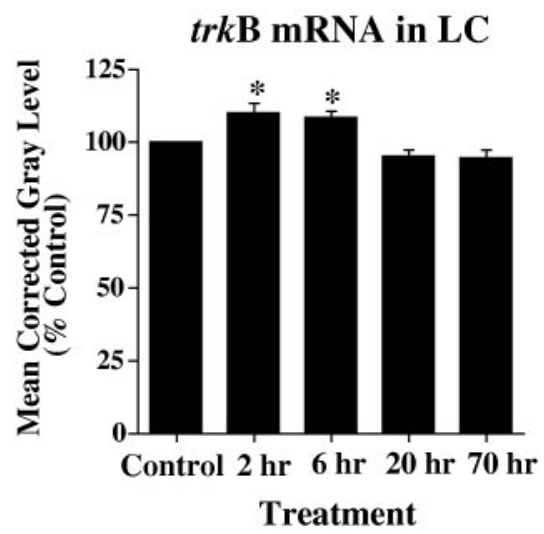

Figure 4. Effect of precipitated opiate withdrawal on $t r k \mathrm{~B}$ mRNA expression in LC. $A$, Film autoradiograms demonstrating trkB mRNA expression in LC of control rats and rats exposed to 2 or $6 \mathrm{hr}$ of opiate withdrawal. $B$, Film autoradiograms of trkB cRNA hybridization in LC in control rats and rats exposed to 20 or $70 \mathrm{hr}$ of opiate withdrawal. $C$, Densitometric analysis of film autoradiograms reveals an increase in trkB mRNA levels at 2 and 6 hr of opiate withdrawal as compared with control $(p<0.05)$, and no changes in trkB mRNA expression at 20 and 70 hr of opiate withdrawal as compared with control. Results are expressed as a percentage of control values. Values are the mean \pm SEM (SEM for 2 and 6 hr control group $= \pm 1.1$; SEM for 20 and $70 \mathrm{hr}$ control group $= \pm 1.7$.) *Significantly increased from control. Scale bar, $500 \mu \mathrm{m}$.

cantly decreased from controls until the $6 \mathrm{hr}$ time point (Hicks et al., 1997).

The early increase in trkC mRNA expression followed by a decrease to below control levels in the LC during opiate withdrawal is difficult to interpret functionally because of the fact that the probe used recognized mRNA transcripts for both the catalytic and noncatalytic isoforms of the receptor (Dixon and McKinnon, 1994; Albers et al., 1996). Therefore, it is unclear whether the changes in trkC mRNA detected in this study are caused by alterations in the levels of the catalytic or noncatalytic transcripts, or both.

Chronic opiate exposure led to a small but significant increase in BDNF mRNA in the LC, with a robust increase observed during opiate withdrawal. It has been hypothesized that BDNF and other neurotrophins may in some cases be responsible for maintenance of neuronal phenotype (Korsching, 1993; Lindsay et al., 1994). Within this context, one possibility is that BDNF acts in a paracrine or autocrine manner in the $\mathrm{LC}$, which is plausible because LC neurons express both BDNF and trkB mRNAs (Seroogy, 1994; Zhang et al., 1998). If so, the increase in BDNF expression could serve to counter the effects of chronic morphine and morphine withdrawal on the biochemistry of these neurons. Future studies with antagonists to BDNF will be needed to examine the validity of this hypothesis. Besides a potential paracrine role for BDNF in the LC, recent evidence suggests that $\mathrm{LC}$ neurons can anterogradely transport BDNF to their projection regions (Fawcett et al., 1998). Because the LC has widespread projections throughout the CNS (Lindvall and Björklund, 1983), this anterogradely transported BDNF may be a trophic factor for many neurotrophin-responsive neuronal populations. Increased expression of BDNF in the LC during morphine treatment and withdrawal could then contribute to adaptations and homeostatic mechanisms that occur in these other brain regions as well.

Neurotrophins and their receptors have been observed to ex- 
A

\section{Control}

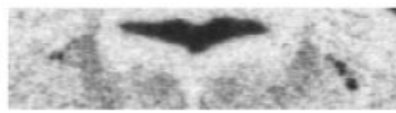

$2 \mathrm{hr}$

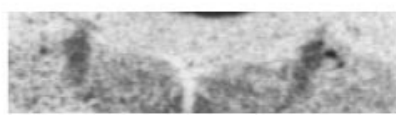

$6 \mathrm{hr}$

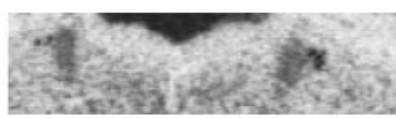

B

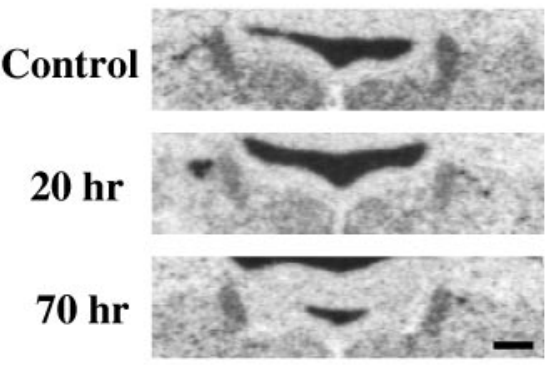

C

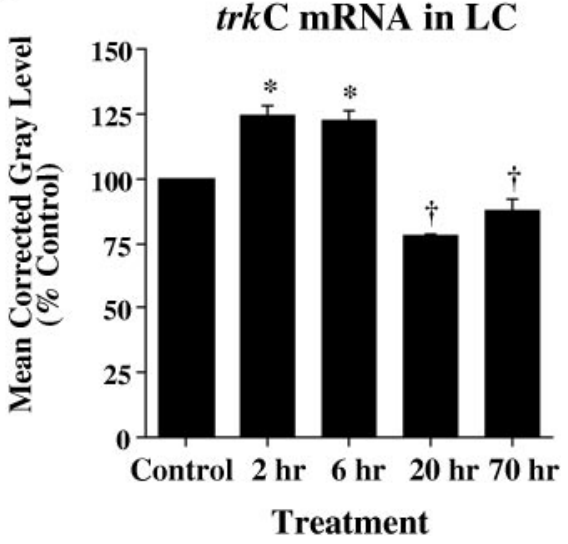

Figure 5. Effect of precipitated opiate withdrawal on trkC mRNA expression in LC. $A$, Film autoradiograms showing the expression of trkC mRNA in LC of control rats and rats exposed to 2 or $6 \mathrm{hr}$ of opiate withdrawal. $B$, Film autoradiograms of trkC mRNA expression in LC in control rats and rats exposed to 20 or $70 \mathrm{hr}$ of opiate withdrawal. $C$, Densitometric analysis of film autoradiograms demonstrates an increase in trkC mRNA levels at 2 and $6 \mathrm{hr}$ of opiate withdrawal as compared with control $(p<0.05)$, followed by a decrease in trkC mRNA levels at 20 and $70 \mathrm{hr}$ of opiate withdrawal as compared with control $(p<0.05)$. Results are expressed as a percentage of control values. Values are the mean \pm SEM (SEM for 2 and 6 hr control group $= \pm 2.7$; SEM for 20 and $70 \mathrm{hr}$ control group $= \pm 3.7$.) *Significantly increased from control. 'Significantly decreased from control. Scale bar, 500 $\mu \mathrm{m}$.

Control

A

BDNF mRNA

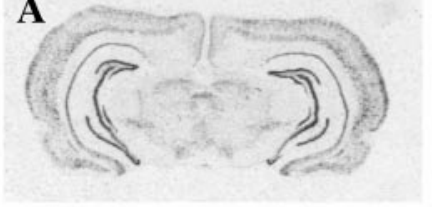

C

NT-3 mRNA

trkB mRNA
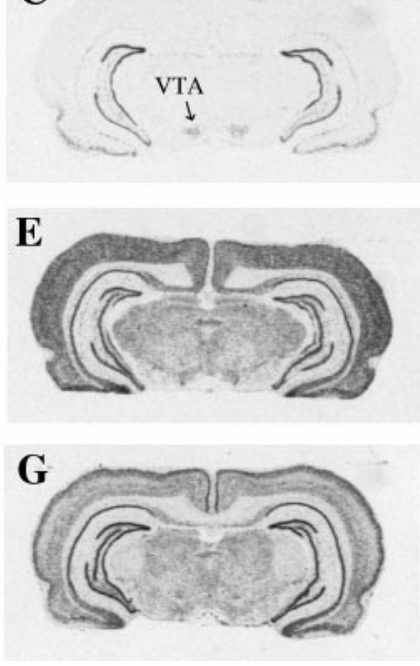

\section{Morphine}

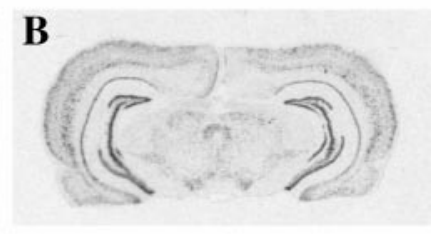

D
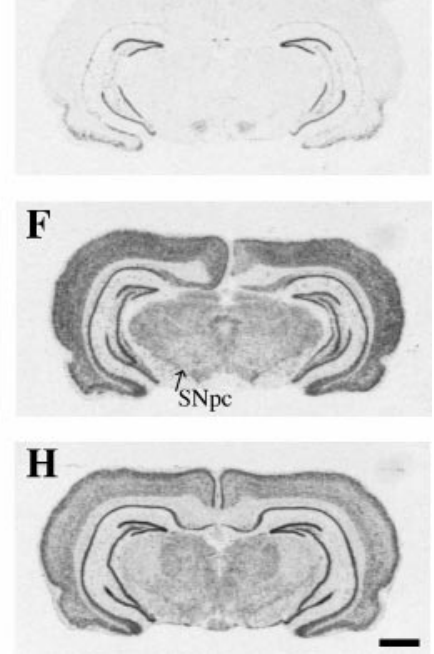

Figure 6. Film autoradiograms of $\operatorname{BDNF}(A, B)$, NT-3 $(C, D), \operatorname{trkB}(E, F)$, and $\operatorname{trkC}(G, H)$ cRNA hybridization in the ventral midbrain of control $(A, C, E, G)$ and morphine-treated $(B, D, F, H)$ rats. Note that no significant alterations in neurotrophin or neurotrophin receptor mRNA levels were observed in VTA after chronic opiate exposure. $S N p c$, Substantia nigra pars compacta. Scale bar, $1710 \mu \mathrm{m}$. hibit plasticity after several manipulations and seem to be especially sensitive to alterations in neuronal activity. The increased neuronal activity observed with seizures leads to increases in BDNF (Ernfors et al., 1991; Isackson et al., 1991; Rocamora et al., 1992; Lindefors et al., 1995; Nibuya et al., 1995; Suzuki et al., 1995) and trkB (Merlio et al., 1993; Lindefors et al., 1995; Nibuya et al., 1995) and decreases in NT-3 (Rocamora et al., 1992; Suzuki et al., 1995) mRNA levels in the hippocampus (for review, see Gall, 1993). It has been suggested that BDNF and its high-affinity receptor trk $\mathrm{B}$ may play a role in neuroprotection (Lindvall et al.,
1992; Merlio et al., 1993) or in the long-term biochemical and morphological changes associated with seizure (Gall, 1993). The early increase in BDNF, trkB, and trkC mRNAs and the delayed decrease in NT-3 and trkC mRNAs in the LC after precipitated opiate withdrawal may be in response to the increase in LC neuronal activity that occurs during withdrawal (Valentino and Wehby, 1989; Rasmussen et al., 1990). LC firing rate is increased within 3 min of precipitated opiate withdrawal, peaks by 15-30 min, and returns to control levels by 3 d (Rasmussen et al., 1990). Of particular interest are the findings that expression of certain 
A

B

BDNF mRNA in VTA

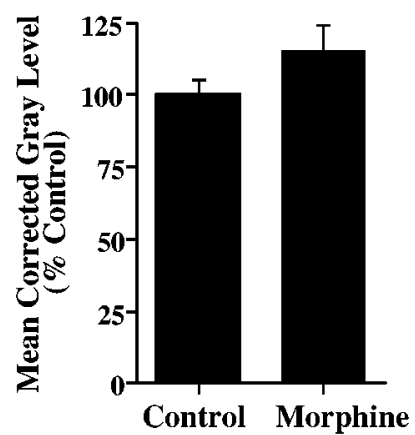

$\mathbf{C}$

trkB mRNA in VTA

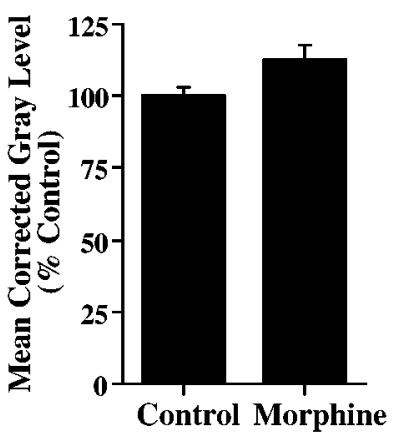

NT-3 mRNA in VTA

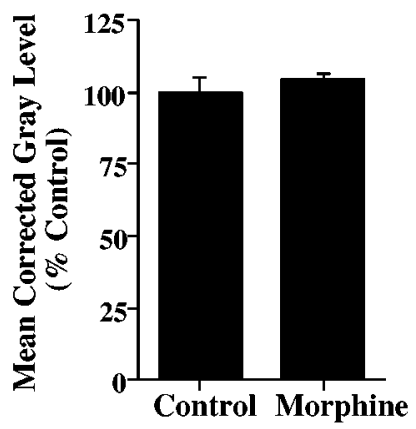

D

trkC mRNA in VTA

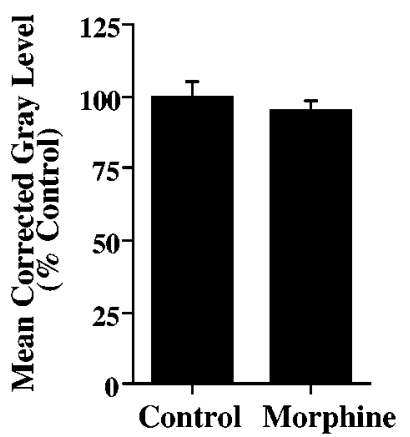

Figure 7. Analysis of $\operatorname{BDNF}(A), \mathrm{NT}-3(B), \operatorname{trkB}(C)$, and trkC $(D)$ mRNA expression in VTA after chronic opiate treatment. No significant alterations in neurotrophin $(A, B)$ or neurotrophin receptor $(C, D)$ mRNA levels were observed in VTA with chronic morphine treatment. Results are expressed as a percentage of control values. Values are the mean \pm SEM.

neurotrophins and their receptors are still significantly altered at $70 \mathrm{hr}$ of withdrawal, a time at which all detectable withdrawal behaviors have dissipated and the neuronal activity of the LC has returned to normal levels (Rasmussen et al., 1990). The persisting adaptations in neurotrophin systems could be involved, therefore, in more protracted aspects of opiate abstinence, phenomena that are well described clinically but have been difficult to detect in laboratory animals (Koob and Nestler, 1997). The hypothesis that BDNF induction in LC neurons during opiate withdrawal is secondary to the increased firing of these neurons is supported by the previous finding that administration of reserpine, which also increases the firing rate of LC neurons (Melia et al., 1992), induces a transient upregulation of BDNF mRNA within LC neurons (Seroogy, 1994).

In contrast to the alterations observed in LC after chronic morphine treatment or withdrawal, there was little regulation of the neurotrophins or their receptor mRNAs within the VTA. In fact, the only change observed was a small but significant increase in trkB mRNA in the VTA at 6 hr of opiate withdrawal. Neurotrophin expression within the VTA has previously been determined to be malleable in adult rodents. BDNF mRNA expression has been observed to be transiently increased in the VTA after 6-hydroxydopamine-induced (Numan and Seroogy, 1994) and

A

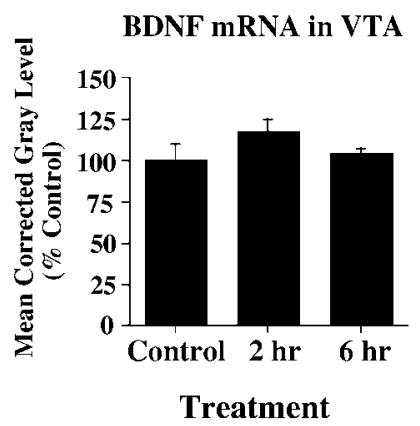

C

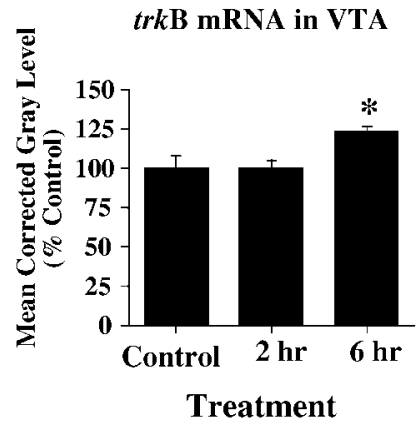

D

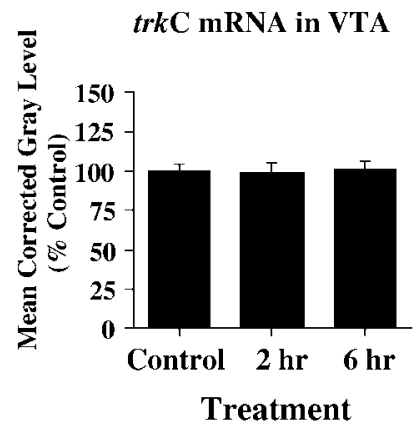

Figure 8. Densitometric analysis of neurotrophin $(A, B)$ and neurotrophin receptor $(C, D)$ mRNA expression in VTA during precipitated opiate withdrawal. No significant alterations in $\operatorname{BDNF}(A), \mathrm{NT}-3(B)$, or trkC $(D)$ mRNA levels were observed in VTA during withdrawal from opiates. $C$, trkB mRNA levels were significantly increased as compared with control at $6 \mathrm{hr}$ of morphine withdrawal $(p<0.05)$. Results are expressed as a percentage of control values. Values are the mean \pm SEM. * Significantly increased from control.

1-methyl-4-phenyl-1,2,3,6-tetrahydropyridine-induced (Hung and Lee, 1996) lesions. This evidence suggests that the lack of changes in the VTA in the present study are not caused by an inability of the neurons to alter neurotrophin expression. It may not be surprising that little regulation of the neurotrophins or their receptor mRNAs was observed in the VTA during opiate withdrawal. Opiates have been shown to acutely inhibit the inhibitory GABAergic neurons in the VTA, thereby activating the dopaminergic neurons (Johnson and North, 1992). Although the electrophysiological activity of dopaminergic neurons during opiate withdrawal is not known, there is indirect evidence that the opiate-induced inhibition of the GABAergic interneurons is reversed during withdrawal, leading to a pronounced inactivation of the VTA dopaminergic neurons (Bonci and Williams, 1997). Despite the lack of regulation of the neurotrophins and receptors themselves, however, previous work has shown a clear modulation of postreceptor signaling proteins in the VTA after chronic morphine treatment (Russell et al., 1994; Berhow et al., 1996).

The results of the present study provide further evidence for the involvement of neurotrophin systems in opiate addiction, particularly in the LC. Although the exact physiological role played by these changes in the neurotrophins and their receptor mRNAs during the course of chronic morphine treatment and withdrawal will require further research, these findings highlight the complex array of adaptations that contribute to the drugaddicted state. 


\section{REFERENCES}

Aghajanian GK (1978) Tolerance of locus coeruleus neurones to morphine and suppression of withdrawal response by clonidine. Nature 267:186-188.

Albers KM, Perrone TN, Goodness TP, Jones ME, Green MA, Davis BM (1996) Cutaneous overexpression of NT-3 increases sensory and sympathetic neuron number and enhances touch dome and hair follicle innervation. J Cell Biol 134:487-497.

Altar CA, Siuciak JA, Wright P, Ip NY, Lindsay RM, Wiegand SJ (1994) In situ hybridization of trkB and $t r k C$ receptor mRNA in rat forebrain and association with high-affinity binding of $\left[{ }^{125} \mathrm{I}\right] \mathrm{BDNF},\left[{ }^{125} \mathrm{I}\right] \mathrm{NT}-4 / 5$ and $\left[{ }^{125} \mathrm{I}\right] \mathrm{NT}-3$. Eur J Neurosci 6:1389-1405.

Aston-Jones G, Shipley MT, Grzanna R (1995) The locus coeruleus, A5 and A7 noradrenergic cell groups. In: The rat nervous system, Ed 2 (Paxinos G, ed), pp 183-213. San Diego: Academic.

Berhow MT, Russell DS, Terwilliger RZ, Beitner-Johnson D, Self DW, Lindsay RM, Nestler EJ (1995) Influence of neurotrophic factors on morphine- and cocaine-induced biochemical changes in the mesolimbic dopamine system. Neuroscience 68:969-979.

Berhow MT, Hiroi N, Nestler EJ (1996) Regulation of ERK (Extracellular Signal Regulated Kinase), part of the neurotrophin signal transduction cascade, in the rat mesolimbic dopamine system by chronic exposure to morphine or cocaine. J Neurosci 16:4707-4715.

Bird SJ, Kuhar MJ (1977) Iontophoretic application of opiates to the locus coeruleus. Brain Res 122:523-533.

Bonci A, Williams JT (1997) Increased probability of GABA release during withdrawal from morphine. J Neurosci 17:796-803.

Dixon JE, McKinnon D (1994) Expression of the trk gene family of neurotrophin receptors in prevertebral sympathetic ganglia. Dev Brain Res 77:177-182.

Duman RS, Tallman JF, Nestler EJ (1988) Acute and chronic opiateregulation of adenylate cyclase in brain: specific effects in locus coeruleus. J Pharmacol Exp Ther 246:1033-1039.

Ernfors P, Bengzon J, Kokaia Z, Persson H, Lindvall O (1991) Increased levels of messenger RNAs for neurotrophic factors in the brain during kindling epileptogenesis. Neuron 7:165-176.

Fawcett JP, Bamji SX, Causing CG, Aloyz R, Ase AR, Reader TA, McLean JH, Miller FD (1998) Functional evidence that BDNF is an anterograde neuronal trophic factor in the CNS. J Neurosci $18: 2808-2821$

Friedman WJ, Ibáñez CF, Hallböök F, Persson H, Cain LD, Dreyfus CF, Black IB (1993) Differential actions of neurotrophins in the locus coeruleus and basal forebrain. Exp Neurol 119:72-78.

Gall CM (1993) Seizure-induced changes in neurotrophin expression: implications for epilepsy. Exp Neurol 124:150-166.

Gall CM, Gold SJ, Isackson PJ, Seroogy KB (1992) Brain-derived neurotrophic factor and neurotrophin-3 mRNAs are expressed in ventral midbrain regions containing dopaminergic neurons. Mol Cell Neurosci 3:56-63.

Grant SJ, Huang YH, Redmond Jr DE (1988) Behavior of monkeys during opiate withdrawal and locus coeruleus stimulation. Pharmacol Biochem Behav 30:13-19.

Guitart X, Hayward M, Nisenbaum LK, Beitner-Johnson DB, Haycock JW, Nestler EJ (1990) Identification of MARPP-58, a morphine- and cyclic AMP-regulated phosphoprotein of $58 \mathrm{kDa}$, as tyrosine hydroxylase: evidence for its expression by chronic morphine in rat brain. J Neurosci 10:2649-2659.

Hicks RR, Numan S, Dhillon HS, Prasad MR, Seroogy KB (1997) Alterations in BDNF and NT-3 mRNAs in rat hippocampus after experimental brain trauma. Mol Brain Res 48:401-406.

Hung H-C, Lee EHY (1996) The mesolimbic dopaminergic pathway is more resistant than the nigrostriatal dopaminergic pathway to MPTP and MPP+ toxicity: role of $B D N F$ gene expression. Mol Brain Res $41: 16-26$.

Hyman C, Hofer M, Barde Y-A, Juhasz M, Yancopoulos GD, Squinto SP, Lindsay RM (1991) BDNF is a neurotrophic factor for dopaminergic neurons of the substantia nigra. Nature 350:230-232.

Hyman C, Juhasz M, Jackson C, Wright P, Ip NY, Lindsay RM (1994) Overlapping and distinct actions of the neurotrophins BDNF, NT-3 and NT-4/5 on cultured dopaminergic and GABAergic neurons of the ventral mesencephalon. J Neurosci 14:335-347.

Isackson PJ, Huntsman MM, Murray KD, Gall CM (1991) BDNF mRNA expression is increased in adult rat forebrain after limbic seizures: temporal patterns of induction distinct from NGF. Neuron 6:937-948.
Johnson SW, North RA (1992) Opioids excite dopamine neurons by hyperpolarization of local interneurons. J Neurosci 12:483-488.

Koob GF, Le Moal M (1997) Drug abuse: hedonic homeostatic dysregulation. Science 278:52-58.

Koob GF, Nestler EJ (1997) The neurobiology of drug addiction. J Neuropsychiatry Clin Neurosci 9:482-497.

Korf J, Bunney BS, Aghajanian GK (1974) Noradrenergic neurons: morphine inhibition of spontaneous activity. Eur J Pharmacol 25:165-169.

Korsching S (1993) The neurotrophic factor concept: a reexamination. J Neurosci 13:2739-2748.

Lindefors N, Brodin E, Metsis M (1995) Spatiotemporal selective effects on brain-derived neurotrophic factor and trkB messenger RNA in rat hippocampus by electroconvulsive shock. Neuroscience 65:661-670.

Lindsay RM, Wiegand SJ, Altar CA, DiStefano PS (1994) Neurotrophic factors: from molecule to man. Trends Neurosci 17:182-190.

Lindvall O, Björklund A (1983) Dopamine- and norepinephrinecontaining neuron systems: their anatomy in the rat brain. In: Chemical neuroanatomy (Emson PC, ed), pp 229-255. New York: Raven.

Lindvall O, Ernfors P, Bengzon J, Kokaia Z, Smith M-L, Siesjö BK, Persson H (1992) Differential regulation of mRNAs for nerve growth factor, brain-derived neurotrophic factor, and neurotrophin-3 in the adult rat brain following cerebral ischemia and hypoglycemic coma. Proc Natl Acad Sci USA 89:648-652.

Maldonado R, Koob GF (1993) Destruction of the locus coeruleus decreases physical signs of opiate withdrawal. Brain Res 605:128-138.

Melia KR, Rasmussen K, Terwilliger RZ, Haycock JW, Nestler EJ, Duman RS (1992) Coordinate regulation of the cyclic AMP system with firing rate and expression of tyrosine hydroxylase in the rat locus coeruleus: effects of chronic stress and drug treatments. J Neurochem 58:494-502.

Merlio J-P, Ernfors P, Kokaia Z, Middlemas DS, Bengzon J, Kokaia M, Smith M-L, Siesjö BK, Hunter T, Lindvall O, Persson H (1993) Increased production of TrkB protein tyrosine kinase receptor after brain insults. Neuron 10:151-164.

Nestler EJ, Aghajanian GK (1997) Molecular and cellular basis of addiction. Science 278:58-63.

Nestler EJ, Tallman JF (1988) Chronic morphine treatment increases cyclic AMP-dependent protein kinase activity in the rat locus coeruleus. Mol Pharmacol 33:127-132.

Nestler EJ, Hope BT, Widnell KL (1993) Drug addiction: a model for the molecular basis of neural plasticity. Neuron 11:995-1006.

Nestler EJ, Berhow MT, Brodkin ES (1996) Molecular mechanisms of drug addiction: adaptations in signal transduction pathways. Mol Psychiatry 1:190-199.

Nibuya M, Morinobu S, Duman RS (1995) Regulation of BDNF and trkB mRNA in rat brain by chronic electroconvulsive seizure and antidepressant drug treatments. J Neurosci 15:7539-7547.

Numan S, Seroogy KB (1994) Increased expression of BDNF mRNA in adult ventral midbrain following acute 6-OHDA lesions of the nigrostriatal pathway. Soc Neurosci Abstr 20:1306.

Numan S, Seroogy KB (1997) Increased expression of trkB mRNA in rat caudate-putamen following 6-OHDA lesions of the nigrostriatal pathway. Eur J Neurosci 9:489-495.

Numan S, Seroogy KB (1998) Expression of trkB and trkC mRNAs by adult midbrain dopamine neurons: a double-label in situ hybridization study. J Comp Neurol 403:298-311.

Paxinos G, Watson C (1986) The rat brain in stereotaxic coordinates, Ed 2. Sydney: Academic.

Rasmussen K, Beitner-Johnson DB, Krystal JH, Aghajanian GK, Nestler EJ (1990) Opiate withdrawal and the rat locus coeruleus: behavioral, electrophysiological, and biochemical correlates. J Neurosci 10:23082317.

Rocamora N, Palacios JM, Mengod G (1992) Limbic seizures induce differential regulation of the expression of nerve growth factor, brainderived neurotrophic factor and neurotrophin- 3 , in the rat hippocampus. Mol Brain Res 13:27-33.

Russell DS, Berhow MT, Widnell KL, Self DW, Nestler EJ (1994) Modulation of neurotrophin receptor tyrosine kinase (RTK) pathways in the mesolimbic dopamine system by drugs of abuse. Soc Neurosci Abstr 20:1102.

Seroogy KB (1994) Transient expression of BDNF mRNA in rat locus coeruleus following acute reserpine administration. Soc Neurosci Abstr 20:1306 
Seroogy KB, Gall CM (1993) Expression of neurotrophins by midbrain dopaminergic neurons. Exp Neurol 124:119-128.

Seroogy KB, Herman JP (1997) In situ hybridization approaches to the study of the nervous system. In: Neurochemistry: a practical approach (Turner AJ, Bachelard HS, eds), pp 121-150. Oxford: Oxford UP.

Seroogy KB, Lundgren KH, Tran TMD, Guthrie KM, Isackson PJ, Gall CM (1994) Dopaminergic neurons in the rat ventral midbrain express brain-derived neurotrophic factor and neurotrophin-3 mRNAs. J Comp Neurol 342:321-334.

Sklair-Tavron L, Nestler EJ (1995) Opposing effects of morphine and the neurotrophins NT-3, NT-4 and BDNF, on locus coeruleus neurons in vitro. Brain Res 702:117-125.

Sklair-Tavron L, Shi W-X, Lane SB, Harris HW, Bunney BS, Nestler EJ (1996) Chronic morphine induces visible changes in the morphology of mesolimbic dopamine neurons. Proc Natl Acad Sci USA 93:1120211207.

Smith MA, Makino S, Altemus M, Michelson D, Hong S-K, Kvetnansky R, Post RM (1995) Stress and antidepressants differentially regulate neurotrophin-3 mRNA expression in the locus coeruleus. Proc Natl Acad Sci USA 92:8788-8792.

Spenger C, Hyman C, Studer L, Egli M, Evtouchenko L, Jackson C, Dahl-Jørgensen A, Lindsay RM, Seiler RW (1995) Effects of BDNF on dopaminergic, serotonergic, and GABAergic neurons in cultures of human fetal ventral mesencephalon. Exp Neurol 133:50-63.

Sternini C, Su D, Arakawa J, Giorgio RD, Rickman DW, Davis BM, Albers KM, Brecha NC (1996) Cellular localization of pan-trk immunoreactivity and trkC mRNA in the enteric nervous system. J Comp Neurol 368:597-607.

Suzuki F, Junier M-P, Guilhem D, Sørensen J-C, Onteniente B (1995) Morphogenetic effect of kainate on adult hippocampal neurons associated with a prolonged expression of brain-derived neurotrophic factor. Neuroscience 64:665-674.

Valentino RJ, Wehby RG (1988) Morphine effects on locus coeruleus neurons are dependent on the state of arousal and availability of external stimuli: studies in anesthetized and unanesthetized rats. J Pharmacol Exp Ther 244:1178-1186.

Valentino RJ, Wehby RG (1989) Locus coeruleus discharge characteristics of morphine dependent rats: effects of naltrexone. Brain Res 488:126-134.

Wise RA (1996) Neurobiology of addiction. Curr Opin Neurobiol 6:243-251.

Zhang L, Herman JP, Lundgren KH, Seroogy KB (1998) Modulation of neurotrophin and neurotrophin receptor mRNA expression in rat locus coeruleus following acute stress. Soc Neurosci Abstr 24:293. 